Uniwersytet Rzeszowski

malgorzata.kulakowskaur@wp.pl

\title{
INTERFERENCJE KULTUROWE NA PRZYKLADZIE IMION POLAKÓW MIESZKAJĄCYCH NA TERENIE KIJOWSKIEGO OKRĘGU KONSULARNEGO
}

Słow a tematyczne: interferencja kulturowa, interferencja językowa, imiona Polaków

Zjawisko interferencji językowej było przedmiotem licznych analiz. Wielu badaczy posługuje się definicją interferencji sformułowaną przez $U$. Weinreicha. Według tej definicji ,interferencja językowa zachodzi w sytuacji bilingwizmu i polega na utrwaleniu odstępstwa od normy jednego z języków i na wprowadzeniu elementów obcojęzycznych, w rezultacie czego dochodzi do zmiany modelu" (Abramowicz 1993: 9). Jak podkreślał K. Feleszko (2002: 106-107), do interferencji językowej dochodzi w sytuacji stałego kontaktu językowego. Ma on miejsce wówczas, gdy danymi językami posługuje się ta sama osoba. Miejscem kontaktu nie jest zatem styk różnych obszarów językowych, lecz konkretni użytkownicy języków. Przemienne używanie przez daną osobę dwóch i więcej języków pozwala ją scharakteryzować jako dwu-/wielojęzyczną.

Kontakt językowy może być uważany za jeden z przejawów kontaktu kultur. K. Feleszko definiuje kulturę jako „stałe sposoby postępowania danej społeczności” (2002: 89). W tej definicji mieści się również system tradycji prawno-obyczajowej danego społeczeństwa. Należą do niego m.in. imiona osobowe. T. Milewski pisał, że „imiona, będąc tworami językowymi, są równocześnie środkiem orientacji w obrębie społeczeństwa, systemem klasyfikacji jego członków. W tych warunkach zachodzi niewątpliwy związek między imiennictwem osobowym a kulturą" (1969: 147). Można zatem uznać, że w zbiorze imion społeczności, która żyje w sytuacji stałego kontaktu dwóch kultur, dochodzi nie tylko do interferencji językowej, ale również do interferencji kulturowej.

W przypadku imion społeczności Polaków na Kijowszczyźnie procesy interferencyjne mogą dotyczyć elementów językowych, takich jak np. grafia, fonetyka czy fleksja imion. Często są także związane z wyborem imienia dla dziecka lub wyborem wariantu własnego imienia, zapisywanego w różnych dokumentach. Analiza imion Polaków mieszkających na tych terenach pozwala zaobserwować nie tylko 
procesy interferencji językowej, ale także interferencję kulturową, którą należy uznać za zjawisko dużo szersze niż interferencja językowa, bo dotyczące różnych sposobów zachowania społeczności. Interferencja kulturowa pojawia się wówczas, gdy rodzic decyduje się na wybór imienia dla dziecka spośród imion obcych systemowi imienniczemu ojczystego języka ${ }^{1}$ lub gdy dorosła osoba, posługując się językiem ojczystym, używa obcego wariantu imienia. Interferencja kulturowa w imionach Polaków mieszkających w Kijowskim Okręgu Konsularnym jest przejawem przenikania elementów obcej kultury (wschodniosłowiańskiej) do kultury rodzimej (polskiej) w sytuacji stałego kontaktu tych dwóch kultur.

Kijowski Okręg Konsularny obejmuje cztery obwody administracyjne w centralnej części Ukrainy: kijowski (razem z Kijowem), kirowgradzki, czernichowski i czerkaski. Polacy przybywali na te ziemie już w czasach Pierwszej Rzeczypospolitej, Kijowszczyzna i Czernichowszczyzna należały bowiem do Wielkiego Księstwa Litewskiego, a potem weszły w skład Rzeczypospolitej. Jako tereny leżące na pograniczu zawsze były miejscem przenikania się różnych kultur. To właśnie te ziemie określano pierwotnie (do XVII w.) mianem Kresów. Po ich utracie w wyniku wojen z Rosją zaczęto nazywać je Ziemiami Oderwanymi. Mimo oderwania od Rzeczpospolitej na jej dawnych Kresach pozostało wielu Polaków. Ponadto w XIX w. wzrósł napływ Polaków do Kijowa. Było to związane z sytuacją po rozbiorach Polski. Podole znalazło się w zaborze rosyjskim i mieszkający tam Polacy łatwiej mogli kształcić swoje dzieci i załatwiać interesy w Kijowie niż we Lwowie, który leżał w granicach Austrii. Na przełomie XIX i XX w. działały tam liczne polskie organizacje i stowarzyszenia o różnym charakterze, wielu Polaków uczyło się na uniwersytecie, prowadziło firmy. Po 1917 r. tereny te znalazły się w obrębie Ukraińskiej Socjalistycznej Republiki Radzieckiej. Część Polaków zdecydowała się wówczas na wyjazd do kraju. Ci, którzy zostali, byli poddawani licznym represjom - za przyznawanie się do narodowości polskiej w latach trzydziestych XX w. (w okresie Wielkiego Terroru) groziło rozstrzelanie lub zesłanie. W latach powojennych bycie Polakiem również nie oznaczało łatwego losu, powodowało utratę wielu możliwości, np. awansu społecznego, studiów. Mimo to na tych terenach przetrwały zwarte skupiska Polaków, m.in. w Fastowie, Białej Cerkwi, Obuchowie, Nieżynie, Browarach i w większych miastach, takich jak Kijów, Czerkasy, Kirowgrad. Ponadto do Kijowa, który był stolicą republiki, przyjeżdżali i osiedlali się Polacy z zachodniej części Ukrainy czy też z terenów należących przed wojną do Rumunii. Przenosili się tu także potomkowie Polaków zesłanych do Kazachstanu lub na Syberię. Obecnie Polacy mieszkający w Kijowskim Okręgu Konsularnym działają w licznych stowarzyszeniach polonijnych, uczęszczają na kursy języka polskiego

\footnotetext{
${ }^{1}$ Język ojczysty jest to język grupy społecznej, który przez jej członków jest uważany za wspólną część składową ich kultury, a w przypadku znalezienia się danej grupy w sytuacji kontaktu językowego, np. migracji — staje się przedmiotem troski i zabiegów zainteresowanych jego rozwojem jako depozytu kulturowego (Feleszko 2002: 74).
} 
i uczestniczą w wydarzeniach kulturalnych związanych z Polską. Po wprowadzeniu w 2008 r. ustawy o Karcie Polaka wiele osób zdecydowało się na poszukiwanie polskich korzeni, naukę języka przodków i złożenie deklaracji o przynależności do narodu polskiego.

W niniejszym artykule zanalizowano wybrane imiona Polaków, których wniosek o wydanie Karty Polaka, złożony w latach 2008-2016 w Wydziale Konsularnym Ambasady RP w Kijowie, został pozytywnie rozpatrzony².

Przepisy wykonawcze do ustawy o Karcie Polaka z 2007 r. (DzU, 2008, nr 48, poz. 282$)^{3}$ określają wzór wniosku. W miejscu przeznaczonym na dane osobowe jest rubryka, w której wnioskodawca wpisuje swoje imię zgodnie z łacińską transkrypcją w ukraińskim paszporcie zagranicznym. Większość wnioskodawców podawała też w tej samej rubryce swoje imię w języku polskim - mogła to być polska transkrypcja (np. imię Yurii, pol. Jurij) lub polski wariant imienia (np. imię Yurii, pol. Jerzy). W instrukcjach wypełniania rubryk nie było jednak informacji o takiej możliwości. Zapewne owe instrukcje były przekazywane w formie ustnej lub w różnego typu poradnikach dla osób składających wnioski, dlatego zdarzają się takie formularze, w których podano tylko imię w transkrypcji z dokumentu tożsamości. Od września 2016 r. obowiązuje nowy wzór wniosku o przyznanie Karty Polaka (DzU, 2016, poz. 1382), w którym przewidziano osobną rubrykę na imię w języku polskim. Analizowane przeze mnie wnioski miały jeszcze starą formę, ale w obu wzorach jest wyraźnie zaznaczone, że dokument należy wypełniać w języku polskim.

Ogółem zebrałam 673 jednostki imiennicze. Podzieliłam je według dwóch kryteriów.

Pierwsze kryterium stanowi występowanie interferencji językowej i kulturowej w imionach, drugie natomiast dotyczy wieku nosicieli imion, który wskazuje, w jakim momencie historii Polaków na dawnych Kresach imię zostało nadane. Według pierwszego kryterium imiona Polaków zostały podzielone na trzy grupy. Pierwsza to imiona, w których występuje interferencja językowa. W drugiej grupie znalazły się imiona, które są przejawem interferencji kulturowej. Trzecią grupę stanowią imiona, które są zapisane zgodnie z polskimi zasadami ortografii i należą do kanonu polskich imion. Są to imiona, w których brak znamion interferencji kulturowej i językowej. Nie będą one przedmiotem niniejszego opracowania.

Drugie kryterium pozwala uchwycić dynamikę procesów interferencji w imionach. Opiera się ono na uwzględnieniu daty urodzenia nosiciela. W ramach tego kryterium zostały wyodrębnione cztery grupy imion. W pierwszej, liczącej 37 jed-

${ }^{2}$ Zebranie imion zapisanych w formularzach wniosków było możliwe dzięki uprzejmości kierownika Wydziału Konsularnego Ambasady RP w Kijowie pana konsula Tomasza Dederki oraz pani konsul Alicji Tomaszczyk.

3 Teksty z dzienników ustaw, na które powołuję się w niniejszym artykule są zamieszczone w Internetowym Systemie Aktów Prawnych (www: http://isap.sejm.gov.pl). 
nostek nazewniczych, są imiona osób urodzonych przed zakończeniem drugiej wojny światowej, czyli przed 1945 r. Osoby te to zarówno ci, którzy urodzili się na terenach przedwojennej Polski lub Rumunii i w wyniku różnych kolei losu zamieszkali na Ukrainie środkowej, jak i ci, którzy pozostali na tych ziemiach po 1917 r. i przetrwali okres represji stalinowskich. Drugą grupę tworzą imiona osób urodzonych w latach powojennych w ZSRR, tzn. od 1945 r. do uzyskania niezależności przez Ukrainę w $1991 \mathrm{r}$. W grupie tej jest 436 imion. Trzecia grupa obejmuje imiona osób urodzonych po 1991 r., lecz przed uchwaleniem ustawy o Karcie Polaka w 2007 r. Znalazło się w niej 158 imion. Ostatnią, czwartą grupę stanowią $42^{4}$ imiona dzieci urodzonych w czasie obowiązywania ustawy, czyli po $2007 \mathrm{r}$.

Interferencję językową $\mathrm{w}$ imionach osób narodowości polskiej składających wnioski o przyznanie Karty Polaka można zaobserwować wówczas, gdy wnioskodawca nie wpisuje polskiej wersji imienia w rubryce danych osobowych, a transkrypcja łacińska imienia z ukraińskiego dokumentu tożsamości nie jest zgodna z polską pisownią. Taka sytuacja występuje w 62 wnioskach, co stanowi 9\% wszystkich zbadanych dokumentów. Transliteracja [wcześniej mowa o transkrypcji] łacińska tych imion to przeważnie zapisy, w których litera y lub $i$ powinna zostać w polskim zapisie zastapiona przez $j$, np. Yuliya, Iurii; litera $v$ przez $w$, np. Ivan, Stanislav; litera $l$ przez $t$, np. Vladyslava, Stanislav.

Pozostawienie jedynie form imion zgodnych z ukraińskimi dokumentami tożsamości może wynikać z niedopatrzenia i nie zawsze jest równoznaczne z interferencją językową w zakresie imion w codziennym użyciu języka polskiego. Takich wątpliwości nie budzi wprowadzenie polskiej wersji imienia w postaci niezgodnej z polską ortografią, co może świadczyć o lukach w opanowaniu języka polskiego. Może być też oznaką braku świadomości, że imię w dokumencie wypełnionym w języku polskim (będącym częścią dokumentacji) potwierdza deklarację polskiej tożsamości narodowej i powinno być zapisane zgodnie z polskimi normami ortograficznymi. Wniosków z błędnie napisanym imieniem w języku polskim jest 21, co stanowi 3\% badanego materiału. Można także zauważyć, że w tego typu przykładach interferencji występuje brak polskich liter i zgodności z polską fonetyką. Błędy te wynikają z przeniesienia liter z łacińskiej transkrypcji. Do najczęściej występujących błędów tego typu należą:

1. Zastępowanie polskiego $t$ literą $l$, np.: Alla, Danilo, Stanislav, Wlodzimierz, Wlodzimier, Wsiewolod.

${ }^{4}$ Dysproporcje liczbowe pomiędzy poszczególnymi grupami osób należy tłumaczyć nie tylko doborem cezury czasowej. Największa grupa to osoby urodzone w latach 1945-1991. Kolejna pod względem liczebności jest grupa młodzieży i dzieci urodzonych w latach 1992-2007. Jest czterokrotnie liczniejsza od grupy najmłodszych Polaków. Z prostego rachunku wynika, że osób urodzonych w okresie 16 lat powinno być dwa razy więcej niż osób urodzonych w przedziale czasowym ośmiu lat. Należy jednak wziąć pod uwagę, że dzięki Karcie Polaka można podjąć bezpłatne studia w Polsce, łatwiej też jest się tutaj osiedlić. Stąd wynika nadreprezentacja osób w wieku studenckim. 
2. Zastępowanie polskiego $w$ literą $v$, np.: Valentyna, Viktoria, Ivan, Vira, Stanislav.

3. Błędy w pisowni imion z literą $j$, np.: Nataliia, Nataliya, Tetjana, Witalii, Witaliy, Zoia.

Pozostałe błędy, które też mogą wynikać z wpływu łacińskiej transkrypcji, występują w trzech imionach: Juzefa, Anastasja, Ihor.

Warto zauważyć, że niekiedy błędy w polskiej wersji imienia mogą wynikać z prób oddania jego brzmienia w języku ukraińskim, np. transkrypcja łacińska Liudmyla, a obok wersja Ludmyła. W przypadku tego dokumentu osoba składająca wniosek wyraźnie zaznaczyła, że chce, aby w języku polskim jej imię brzmiało tak, jak zostało zapisane: [ludmyła]. Tylko ten przypadek został udokumentowany, a mogło być ich więcej. Ustalenie, ile błędów w polskich wersjach imion wynika ze świadomego wyboru, jest trudne, ponieważ w dokumentacji brak uzasadnień zapisu polskiego imienia.

W najstarszej grupie wiekowej, czyli wśród osób urodzonych przed 1945 r., nie ma błędów w polskich wersjach imion, a brak imienia w polskiej grafii wystapił w ośmiu wnioskach. W drugiej, najliczniejszej, grupie jest 10 imion, które nie są zapisane zgodnie z polskimi zasadami ortograficznymi, natomiast w 46 wnioskach w ogóle ich nie ma. Także w trzeciej grupie wiekowej 10 formularzy zawiera polskie imiona z błędami, a w ośmiu zupełnie ich brak. W grupie czwartej — najmłodszych Polaków — wniosek wypełniał rodzic (posiadający już Kartę Polaka) i znalazł się tu tylko jeden błędny zapis polskiego imienia.

Nie ma natomiast formularzy bez wpisanego polskiego imienia. Proporcjonalnie najwięcej błędów w zapisie imienia wystapiło w trzeciej grupie wiekowej, czyli wśród osób urodzonych po 1991 r., co świadczy o słabszej znajomości języka polskiego wśród młodego pokolenia Polaków mieszkających w Kijowskim Okręgu Konsularnym.

Interferencja kulturowa w imionach Polaków, które są zapisywane we wnioskach o przyznanie Karty Polaka, może przejawiać się na różne sposoby. Jednym z nich jest wybór wschodniosłowiańskiego wariantu imienia w sytuacji, gdy możliwe jest użycie polskiego wariantu, np.: Jurij zamiast Jerzy. Za kryterium pozwalające ustalić, czy polski odpowiednik imienia wschodniosłowiańskiego jest znany wśród Polaków w Kijowskim Okręgu Konsularnym, przyjęłam występowanie danego imienia w polskim wariancie we wnioskach, które były składane przez inne osoby. Nie każde imię, które w wydawanych w Polsce słownikach imion ma polski odpowiednik, spełnia to kryterium, np. imię Wasyl, jak podaje Słownik imion Jana Grzeni (2002: 69), jest rosyjskim odpowiednikiem polskiego imienia Bazyli; żaden z wnioskodawców o tym imieniu nie wybrał jednak polskiej wersji.

Za sytuację wyboru wschodniosłowiańskiego wariantu imienia, gdy w społeczności polskiej w badanym obszarze jest on znany, uznaję zarówno wpisanie popraw- 
nej polskiej transkrypcji imienia wschodniosłowiańskiego, np. Yurii (transkrypcja łacińska) - Jurij (polski odpowiednik), jak i sytuację, gdy polski wariant zawiera błędy, np. Nataliia (transkrypcja łacińska) - Natalyia (imię wpisane jako polski odpowiednik; prawidłowa transkrypcja wschodniosłowiańskiego wariantu imienia to Natalija). Pomijam przykłady, w których interferencja uwidacznia się tylko na poziomie grafii, czyli postaci imion typu: Vanda, Stanislav.

45 wnioskodawczyń nie użyło polskiego wariantu imienia. Ogółem liczba żeńskich imion wschodniosłowiańskich, których osoby wnioskujące o nadanie Karty Polaka nie zmieniły na polskie odpowiedniki, wynosi 16 . Dokładnie dwa razy więcej kobiet (90) wybrało polski wariant imienia. Szczegółowo sytuację braku wyboru wariantu polskiego imienia żeńskiego prezentuje tabela 1.

Tabela 1. Zachowane wschodniosłowiańskie imiona żeńskie w sytuacji, gdy istnieje polski odpowiednik

\begin{tabular}{|c|c|c|c|c|}
\hline Lp. & $\begin{array}{c}\text { Wschodni } \\
\text { wariant imienia }\end{array}$ & $\begin{array}{c}\text { Liczba osób, } \\
\text { które wybrały wariant } \\
\text { wschodni }\end{array}$ & $\begin{array}{l}\text { Polski wariant } \\
\text { imienia }\end{array}$ & $\begin{array}{l}\text { Liczba osób, które } \\
\text { wybrały polski } \\
\text { odpowiednik }\end{array}$ \\
\hline 1. & Alisa & 1 & Alicja & 2 \\
\hline 2. & Anastasia & 1 & \multirow{2}{*}{ Anastazja } & \multirow{2}{*}{7} \\
\hline 3. & Anastasija & 2 & & \\
\hline \multirow{2}{*}{4.} & \multirow{2}{*}{ Ganna } & \multirow{2}{*}{1} & Hanna & 2 \\
\hline & & & Anna & 1 \\
\hline 5. & Iwanna & 1 & Joanna & 1 \\
\hline 6. & Julija & 5 & Julia & 18 \\
\hline 7. & Marija & 4 & Maria & 14 \\
\hline 8. & Nadia & 2 & Nadzieja & 1 \\
\hline 9. & Natalija & 4 & \multirow{2}{*}{ Natalia } & \multirow{2}{*}{19} \\
\hline 10. & Natalyia & 1 & & \\
\hline 11. & Nina & 3 & Janina $^{5}$ & 1 \\
\hline 12. & Oksana & 6 & Ksenia & 1 \\
\hline 13. & Oleksandra & 2 & Aleksandra & 2 \\
\hline 14. & Olena & 10 & Helena & 14 \\
\hline 15. & Sofija & 1 & Zofia & 2 \\
\hline 16. & Wiktorija & 1 & Wiktoria & 5 \\
\hline
\end{tabular}

${ }^{5}$ Według J. Grzeni (2002: 256) rosyjskim odpowiednikiem imienia Janina jest Ivanna, lecz przy haśle dotyczącym imienia Nina autor zauważa, że „dziś w Polsce jest [ono] przede wszystkim skróconą formą od żeńskiego imienia Antonina lub Janina". 
Polskiego wariantu imienia nie użyło 33 wnioskodawców. Ogółem liczba męskich imion wschodniosłowiańskich, których osoby wnioskujące o nadanie Karty Polaka nie zmieniły na polskie odpowiedniki, wynosi 13. Spośród wnioskodawców 77 osób wybrało polskie warianty imienia. Szczegółowo sytuację braku wyboru wariantu polskiego imienia męskiego prezentuje tabela 2.

Tabela 2. Zachowane wschodniosłowiańskie imiona męskie w sytuacji, gdy istnieje polski odpowiednik

\begin{tabular}{|c|l|c|l|c|}
\hline Lp. & $\begin{array}{c}\text { Wschodniosłowianski } \\
\text { wariant imienia }\end{array}$ & $\begin{array}{c}\text { Liczba osób, które } \\
\text { wybrały wariant } \\
\text { wschodni }\end{array}$ & $\begin{array}{c}\text { Polski wariant } \\
\text { imienia }\end{array}$ & $\begin{array}{c}\text { Liczba osób, które } \\
\text { wybrały polski } \\
\text { odpowiednik }\end{array}$ \\
\hline 1. & Aleksandr & 2 & Aleksander & 16 \\
\hline 2. & Oleksandr & 2 & Anatol & 2 \\
\hline 3. & Anatolij & 5 & Andrzej & 11 \\
\hline 4. & Andrij & 1 & Eliasz & 2 \\
\hline 5. & Ilia & 4 & Jan & 3 \\
\hline 6. & Iwan & 5 & Eugeniusz & 3 \\
\hline 7. & Jewgenij & 2 & Jerzy & 8 \\
\hline 8. & Jurij & 4 & Konstanty & 3 \\
9. & Kostiantyn & 2 & Konstantyn & 3 \\
\hline 10. & Michaito & 2 & Michat & 9 \\
\hline 11. & Sergiej & 1 & Sergiusz & 5 \\
\hline 12. & Serhij & 1 & Włodzimierz & 12 \\
\hline 13. & Wolodymyr & 2 & & \\
\hline
\end{tabular}

W sumie 78 osób wybrało wschodniosłowiańską wersję imienia własnego lub niepełnoletniego dziecka (w kilku przypadkach). Te decyzje są dużo rzadsze niż decyzje o wpisaniu polskiego wariantu imienia. Ogółem w sytuacji, gdy istniała możliwość wyboru wariantu, 170 osób wybrało polski, co daje liczbę ponad dwukrotnie większą niż liczba osób decydujących się na zapis w wersji wschodniosłowiańskiej. Liczba ta jeszcze wzrośnie, gdy uwzględnimy sytuacje, w których wszyscy Polacy składający wniosek o wydanie Karty Polaka wybrali polski wariant, np. osoby o imieniu Mykoła zawsze wybierały wariant Mikołaj, podobnie imię Galyna zawsze ma polski odpowiednik Halina. Takie decyzje dotyczą 43 imion. Są to zarówno imiona, które pojawiły się raz w badanym zbiorze, np. Tymofij — polski odpowiednik Tymoteusz, jak i imiona o wyższej frekwencji, np. pięć kobiet o imieniu Kateryna wybrało polską wersję imienia Katarzyna.

Decyzje dotyczące zapisu imienia mogą świadczyć o poszukiwaniach polskiej tożsamości. Analiza liczbowa tych imion pokazuje świadome wybory dorosłych 
osób, które przed konsulem RP deklarują przynależność do narodu polskiego. Wybór polskiego lub wschodniosłowiańskiego brzmienia imienia ma wartość symboliczną — jest wyborem między wersją imienia, którą zna otoczenie i której wnioskodawca używa w kontaktach oficjalnych, a wersją polską, która symbolizuje przynależność do narodu polskiego i deklaruje tym samym podtrzymywanie polskich tradycji.

W polskich i wschodniosłowiańskich systemach imienniczych możemy wyróżnić imiona, które są swoiste dla jednego systemu i nie mają odpowiednika w drugim; imiona, dla których istnieją w każdym z systemów warianty, oraz imiona, które mają tę samą postać fonetyczną. Analiza dokonanych wyborów imienniczych w poszczególnych grupach wiekowych wskazuje, że najmniej imion, które mogą mieć wschodniosłowiańską i polską postać, noszą najstarsi posiadacze Karty Polaka. Wśród 37 osób tylko sześć ma takie imiona. W tej grupie jako polską wersję imienia cztery osoby zapisały we wniosku imiona wschodniosłowiańskie, a dwie ich polski odpowiednik. Proporcjonalnie najwięcej imion wschodniosłowiańskich, które mogą mieć polski odpowiednik, noszą Polacy urodzeni w latach 1991-2008. Spośród 158 jednostek onimicznych 66 to imiona, które mają w badanym materiale i polskie, i wschodniosłowiańskie odpowiedniki. Polska wersja imienia była wpisana w 50 wnioskach, lecz tylko 16 osób wybrało wersję wschodniosłowiańską. W grupie 436 imion Polaków urodzonych w powojennych latach w ZSRR 167 to imiona, które mają w badanym materiale polskie i wschodniosłowiańskie warianty. Polską wersję imienia wybrało 114 osób, 53 osoby natomiast - wschodniosłowiańską. Wśród 42 imion dzieci urodzonych po 2008 r. jest dziewięć takich, które mogą mieć wersję wschodniosłowiańską i polską. Rodzice, wypełniając wniosek, w pięciu przypadkach zadecydowali o wpisaniu wschodniosłowiańskiej wersji imienia, a w czterech wybrali wersję polską.

Kolejnym przejawem interferencji kulturowej w imionach Polaków mieszkających w Kijowskim Obwodzie Konsularnym jest wybór imienia, które występuje w polskim systemie imienniczym bardzo rzadko i jest jednoznacznie kojarzone z obcym (w tym wypadku najczęściej prawosławnym) kręgiem kulturowym. Wybór imienia najczęściej jest decyzją rodziców, za którą kryją się różne powody. Przyjmuję, że imiona, które według opracowania K. Rymuta (1995) mają mniej niż 10 tys. nosicieli, czyli według C. Kosyla (2004: 374) są bardzo rzadkie, wyjątkowe i sporadyczne, nie należą do polskiego kanonu imienniczego. W rozumieniu potocznym nie są to typowe polskie imiona.

Porównanie imion Polaków mieszkających w Kijowskim Okręgu Konsularnym z kanonem imion polskich, czyli zbiorem imion często występujących w Polsce, pozwoli ustalić, czy wybór imienia dla dziecka był podyktowany jego „polskością” (imię typowe dla polskiego systemu), czy też dbałością o to, by imię nie wyróżniało dziecka spośród rówieśników. Porównanie to pokaże też postawy rodziców, którzy, wybierając imię dla dziecka, kierowali się różnymi motywami. Często wybierali imię o brzmieniu podobnym do polskiego, ponieważ urzędowy spis imion 
nie zawierał imienia, które chcieli nadać dziecku. Taką sytuację opisuje informatorka O. Pavliuk:

(Rodzice) chcieli chociaż jedną córkę nazwać po polsku - Janinq. Ale jak przyszli rodzice zapisać mnie do urzędu, to powiedziano im, że takiego imienia nie ma, że to jest z obcego imienia Żanina, i można zapisać Żanna. Rodzice zgodzili się, bo nie chcieli się kłócić. W domu siostrę zwano Janq, a gdy poszła do szkoły, to tam i na podwórku nazywano ją Żanna i potem w domu też (2015: 190).

$\mathrm{W}$ okresie najgorszych represji, czyli w latach trzydziestych $\mathrm{XX}$ w. (czasy Wielkiego Terroru), Polacy często nadawali dziecku imię, które nie sugerowało narodowości, by nie narażać rodziny na niebezpieczeństwo. Takie sytuacje opisuje H. Krasowska:

By uchronić się od śmierci czy też zesłania, rodzice nadawali celowo swym dzieciom imiona rosyjskie, lecz w niektórych przypadkach polskie pochodzenie zdradzało imię ojca w postaci otczestwa. Pod koniec lat trzydziestych XX wieku Polacy za pochodzenie byli rozstrzeliwani i zsyłani na Syberię. Zarzucano im współpracę z polskim wywiadem itd. Jeżeli więc ktoś nazywał się Jan Janowicz Lisiecki, to polskie pochodzenie od razu zdradzało imię i otczestwo. Aby zmniejszyć strach przed władzami, dzieciom nadawano imiona, które nie wskazywały na polskie pochodzenie, na przykład Iwan Ludwikowicz Pawlikowski - imię już nie ujawniało pochodzenia, ale imię ojca wciąż ciążyło i narażało na niebezpieczeństwa. Do dzisiaj respondenci na Zaporożu i Doniecku niechętnie nadają polskie imiona swoim dzieciom (2012: 287).

Najpopularniejsze wśród Polaków mieszkających w Kijowskim Okręgu Konsularnym imiona żeńskie to: Julia (23) ${ }^{6}$, Maria (20), Helena (19), Ludmita (16), Natalia (15), Olga (13), Irena (12), Olena (11), Walentyna (11) oraz Tetiana (10). Spośród imion męskich najbardziej popularne są: Aleksander (16), Włodzimierz (13), Stanisław (13), Witalij (12), Andrzej (10), Jerzy (10) i Michat (10).

Spośród tych 17 najczęstszych męskich i żeńskich imion Polaków nadawanych w Kijowskim Okręgu Konsularnym tylko trzy zalicza się w Polsce do imion wyjątkowych, sporadycznych lub bardzo rzadkich. Są to: Ludmiła (8165) ${ }^{7}$, Olena (217), Witalij (47). Imię Tetiana nie występuje natomiast w polskim systemie imienniczym. Duża popularność wymienionych imion wśród mniejszości polskiej świadczy o przenikaniu do systemu imienniczego Polaków mieszkających na terenach centralnej Ukrainy imion wschodniosłowiańskich i dowodzi silnej interferencji kulturowej.

Wśród imion nieco rzadziej wybieranych sytuacja jest podobna. Imiona noszone przez cztery do ośmiu kobiet to: Alina (8), Wiktoria (8), Anastazja (8), Halina (7), Tatiana (7), Anna (6), Jana (6), Katarzyna (6), Oksana (6), Weronika (6), Hanna (5), Janina (5), Ałta (4), Inna (4), Nina (4) i Rustana (4).

${ }^{6} \mathrm{~W}$ nawiasie jest podana liczba imion wyekscerpowanych z formularzy wniosków o nadanie Karty Polaka.

${ }^{7}$ W nawiasie podano liczbę nosicieli imienia w Polsce według K. Rymuta (1995). 
Imiona męskie używane przez czterech do dziewięciu nosicieli to: Oleg (9), Pawet (9), Władysław (9), Eugeniusz (8), Mikołaj (8), Roman (8), Wiktor (8), Jan (6), Anton (5), Dymitr (5), Iwan (5), Sergiusz (5), Anatol (4), Artem (4), Ilia (4), Maksym (4), Oleksandr (4) i Rusłan (4).

W tej grupie wyraźnie zaznacza się też przenikanie imion wschodniosłowiańskich do zasobu antroponimicznego wykorzystywanego przez Polaków badanego regionu. 16 spośród 35 imion o średniej frekwencji używanych przez Polaków w Kijowskim Okręgu Konsularnym należy do najrzadszych w Polsce. Są to: Tatiana (5095), Anatol (4002), Sergiusz (3598), Dymitr (1661), Maksym (751), Oksana (392), Oleg (321), Atta (158), Jana (119), Iwan (116), Inna (57), Anton (42), Ilia (34), Artem (15), Rusłan (15) i Rusłana (4). Ukraińskie imię Oleksandr (wariant imienia Aleksander), które też należy do grupy imion o średniej frekwencji, nie zostało zanotowane przez K. Rymuta (1995).

W ostatniej grupie, która liczy 236 jednostek imienniczych, również jest widoczna interferencja kulturowa w zakresie wyboru imion. 101 osób ma imiona uważane w Polsce za rzadkie. Zestawienie wszystkich grup pozwala stwierdzić, że prawie połowa mieszkańców Kijowskiego Okręgu Konsularnego starających się o Kartę Polaka nosi imiona mało popularne w naszym kraju, co wskazuje na silną interferencję kulturową w imiennictwie polskim na tych terenach. Należy jednak podkreślić, że wśród najpopularniejszych imion w społeczności polskiej na Ukrainie środkowej jest najmniej imion typowo wschodniosłowiańskich. Większość z nich to imiona popularne w obu systemach nazewniczych.

Analiza nadanych imion w poszczególnych grupach wiekowych wykazała, że wśród najstarszych Polaków z Kijowskiego Obwodu najwięcej osób nosi imiona częste w Polsce. Tylko 12 imion spośród 37 można zaliczyć do rzadkich i nie zawsze są to imiona wschodniosłowiańskie. W tej niewielkiej grupie pojawiają się imiona modne w Polsce w latach dwudziestych i trzydziestych XX w., takie jak Rita czy Nelli. W kolejnej grupie wiekowej, do której należą osoby urodzone na Kijowszczyźnie po 1945 r., aż 199 imion (prawie połowa) to według słownika K. Rymuta (1995) imiona rzadko używane w Polsce. Spośród imion osób urodzonych na wolnej Ukrainie 79 jest zaliczanych w Polsce do rzadkich, co także stanowi dokładnie połowę imion należących do tej grupy (a jest ich 158). W ostatniej grupie są 42 imiona dzieci urodzonych po uchwaleniu ustawy o Karcie Polaka, a 16 z nich zaliczanych jest w Polsce do imion rzadkich (około 40\%).

Imiona Polaków mieszkających w krajach byłego ZSRR były przedmiotem badań językoznawców (por.: Pavliuk 2015; Krasowska 2012; Werenicz 1993). Autorzy tych opracowań dostrzegają procesy interferencyjne w imiennictwie Polaków zarówno w zakresie rozregulowania norm językowych (Werenicz 1993: 359), jak i przenikania imion wschodniosłowiańskich do zasobu imion używanych przez Polaków na terenach byłego ZSRR (tamże; Krasowska 2012: 287, Pavliuk 2015: 190-191). Prezentowany w niniejszym opracowaniu materiał imienniczy różni się jednak od 
materiału wykorzystanego w cytowanych pracach. Ich autorzy korzystali z takich źródeł, jak: wywiady z informatorami, dane z miejscowych urzędów, napisy nagrobne. Z badań tych wynika, że przed sąsiadami, którzy nie należeli do mniejszości polskiej, czy przed urzędnikami państwowymi, Polacy z różnych powodów starali się nie eksponować narodowości. Jednym ze sposobów ukrywania narodowości był wybór niepolskiego imienia. W systemie imienniczym społeczności polskiej na terenie dawnego ZSRR znalazło się więc dużo nowych imion wschodniosłowiańskich, można też było zaobserwować dążenie do zamiany tradycyjnych imion polskich na formalnie zbliżone do nich, lecz nieidentyczne znaczeniowo imiona typu wschodniosłowiańskiego (Werenicz 1993: 361).

Osoby ubiegające się o przyznanie Karty Polaka, składając dokumenty, rozmawiając z konsulem RP i urzędnikami w polskich placówkach dyplomatycznych, oświatowych czy kulturalnych, nie mają powodów, by ukrywać swoje pochodzenie - wręcz przeciwnie, udowodnienie polskiego pochodzenia jest jednym z warunków otrzymania Karty Polaka. Dlatego badając imiona zapisane we wnioskach o przyznanie tego dokumentu, można zaobserwować tendencje przeciwstawne do przedstawionych przez W. Werenicza (1993: 361) dążeń do ukrywania narodowości. Imiona wschodniosłowiańskie są zastępowane polskimi wersjami, które często są tylko zbliżone do nich formalnie (np. imię Jegor zastąpione przez Jerzy). Analiza imion w poszczególnych grupach wiekowych pokazuje, że polskie warianty wpisywane do Karty Polaka są dwukrotnie częściej wybierane niż wschodniosłowiańskie, przy czym największe nasilenie tego zjawiska można zaobserwować wśród osób urodzonych w powojennych latach w ZSRR. Również rozregulowanie norm językowych, wyrażające się w niepoprawnych zapisach polskiego imienia, stanowi niewielki odsetek badanego materiału. We wnioskach nie występowały imiona spieszczone czy derywowane, a rozregulowanie norm dotyczyło przede wszystkim grafii. Zarówno wybór polskiego wariantu, jak i prawidłowy zapis imienia w formularzu są związane tylko z wypełnianiem wniosku o przyznanie Karty Polaka. Wybór imienia dla dziecka jest natomiast decyzją, która wpływa na życie jego i rodziny, stąd też w badanym materiale bardzo wiele imion (ponad połowa) to imiona, które są w Polsce rzadkie, a charakterystyczne dla wschodniosłowiańskiego systemu imienniczego. Wydawać by się mogło, że będzie ich najwięcej wśród najstarszych Polaków (czyli urodzonych w okresie ostrych represji — w latach trzydziestych XX w.), lecz w tej grupie jest najmniej imion wschodniosłowiańskich. Liczba nadawanych imion wschodniosłowiańskich wzrastała w ZSRR po drugiej wojnie światowej i w pierwszych latach istnienia Ukrainy. Obecnie można zauważyć niewielką tendencję spadkową. W grupie imion dzieci urodzonych po 2008 r., czyli po wprowadzeniu ustawy o Karcie Polaka, liczba imion wschodniosłowiańskich stanowi $40 \%$ wszystkich ${ }^{8}$. W związku z tym należy uznać, że spadek liczby wschodniosło-

${ }^{8} \mathrm{Z}$ wnioskiem o przyznanie Karty Polaka dla dziecka występuje rodzic, który Kartę Polaka już posiada. 
wiańskich imion w najmłodszej grupie jest niewielki. Podobnie jak na południowym wschodzie Ukrainy (Krasowska 2012: 287), także na terenach centralnej Ukrainy Polacy niechętnie nadają dzieciom polskie imiona. Przyczyną takiego stanu rzeczy jest na pewno dawna polityka językowa, która obejmowała cały obszar ZSRR. K. Feleszko zauważa:

Była to polityka centralizacji $[. .$.$] językowej. Instrumentem sowietyzacji stał się bowiem język.$ Język rosyjski, bez żadnych osłonek narzucany jako państwowy, był nie tylko ideologizowany, lecz niemal sakralizowany. Taka jest uroda systemów totalitarnych. [...] Inne języki zostały w praktyce zepchnięte do sfer nieprestiżowych [...]. Nietrudno sobie wyobrazić, jak nisko w skali prestiżu znalazły się języki grup niecieszących się sympatią władz radzieckich. Do takich grup należeli Polacy. Gdy zaś mówiący orientuje się, że jego język jest niepełnowartościowy, a więc nieprzydatny do obsługiwania wszystkich sfer życia, w tym głównie prestiżowych, rośnie jego obojętność na interferencje ze strony języka prestiżowego. Tym też można tłumaczyć postępującą rusyfikację młodszych pokoleń Polaków na Bukowinie i w ZSRR (2002: 82-83).

W wyniku tej polityki językowej system imienniczy Polaków w ZSRR, podobnie jak język polski w ogóle, poniósł najwięcej szkód - szybko zaczął wchłaniać elementy wschodniosłowiańskie. Znaczący był także, jak zauważa W. Werenicz (1998: 359), brak wsparcia ze strony takich instytucji, jak Kościół czy polska szkoła.

Można zastanawiać się, czy możliwy jest powrót do sytuacji sprzed czasów ZSRR. Mimo przepisów, które obecnie pozwalają nadawać dzieciom urodzonym na Ukrainie imiona zgodne z życzeniem rodziców, nadal jednak trudno im podjać decyzję o nadaniu dziecku imienia, które by go wyróżniało spośród innych osób noszących imiona wschodniosłowiańskie. Znacznie lepiej troska o język ojczysty przejawia się w poprawnym zapisywaniu polskich wariantów imienia oraz w decyzjach, by wybierać polski odpowiednik imienia wschodniosłowiańskiego.

\section{LITERATURA}

Abramowicz Z. 1993: Imiennictwo Żydów białostockich a zjawisko interferencji językowej, [w:] S. Warchoł (red.), Systemy onomastyczne $w$ słowiańskich gwarach mieszanych i przejściowych, „Rozprawy Slawistyczne” 7, Wyd. UMCS, Lublin, s. 9-23.

Feleszko, K. 2002: Bukowina moja miłość. Język polski na Bukowinie Karpackiej do 1945 r., red. A. Żor, t. 1, Slawistyczny Ośrodek Wydawniczy, Warszawa.

Grzenia J. 2002: Stownik imion, PWN, Warszawa.

Kosyl C. 2004: Uwagi o geografii imion osobowych w Polsce, [w:] M. Wojtak, M. Rzeszutko (red.), W kregu wiernej mowy, Wyd. UMCS, Lublin, s. 373-382.

Krasowska H. 2012: Mniejszość polska na południowo-wschodniej Ukrainie, Slawistyczny Ośrodek Wydawniczy, IS PAN, Warszawa.

Milewski T. 1969: Indoeuropejskie imiona osobowe, Ossolineum, Wrocław.

Pavliuk O. 2015: Adaptacja kulturowa wybranych grup etnicznych, w tym Polaków, na poczqtku XXI wieku (na przykładzie obwodu zaporoskiego), „Biblioteka Postscriptum Polonistycznego” V, s. 185-197, http://www.postscriptum.us.edu.pl/pdf/bps2015_5_12.pdf. (dostęp 30 XI 2016). 
Rymut K. 1995: Stownik imion wspótcześnie w Polsce używanych, IJP PAN, Kraków.

Werenicz W. 1993: Procesy interferencyjne w imiennictwie osobowym Polaków w bylym ZSRR, cz. II: Imiona i formy nazywania, [w:] S. Warchoł (red.), Gwary mieszane i przejściowe na terenach stowiańskich, „Rozprawy Slawistyczne” 7, Wyd. UMCS, Lublin, s. 355-364.

Internetowy System Aktów Prawnych, http://isap.sejm.gov.pl/ (dostęp 30 XI) 2016.

\section{CULTURAL INTERFERENCE IN THE NAMES OF POLES LIVING IN THE KIEV CONSULAR DISTRICT}

\section{SUMMARY}

This paper describes the phenomenon of cultural and language interference in the names of Poles living in the Kiev Consular District. The names were selected out of 673 granted requests for the Card of the Pole. According to the regulations, the names specified in the Card of the Pole should be in conformity with the transcript in the applicant's identity document. The Act on the Pole's Card (Ustawa o Karcie Polaka) allows Polish language transcription of the holder's name. An analysis of the names from the applications for issue of the Card of the Pole shows that some people decided to keep to the Latin transcription of their name entered in their Ukrainian passport. The said forms are not always compliant with the Polish spelling. Lack of forms following the Polish spelling (like Yurii, Iuliya) is a manifestation of language interference, namely implementation of foreign language elements to the mother tongue of bilingual persons. Forms of that type represent only a slight percentage of the researched names. Cultural interference, that is, penetration of the domestic culture by elements of other culture has a much bigger coverage. A manifestation of cultural interference in selection of names is when an Eastern Slavonic version of a name is left when it is possible to use its Polish equivalent (for instance choosing the Polish transcription of the name Yuriii as Jurij, instead of Polish Jerzy). Cultural interference occurs also when children are given names that are not included in the Polish name canon. The reasons for interference are: poor knowledge of Polish that is now often learnt from scratch; a sample application for the Card of the Pole (applicable by September 2016) where it was not clearly stated that a Polish version of the name may be entered; or a long-term influence of the totalitarian system, when - in certain periods disclosure of Polish origin would entail repressions. Despite of political changes, parents still prefer to give their children names that are present in both onymic systems.

Ke y w ords: cultural interference, language interference, names of Poles 